\title{
Impacts of land use changes and climate variability on transboundary Hirmand River using SWAT
}

\author{
Mohammadreza Hajihosseini, Hamidreza Hajihosseini im, \\ Saeed Morid Im, Majid Delavar and Martijn J. Booijwa
}

\begin{abstract}
Many river basins are facing a reduction of flows which might be attributed to changes in climate and human activities. This issue is very important in transboundary river basins, where already existing conflicts about shared water resources between riparian countries can easily escalate. The decrease of streamflow in the transboundary Hirmand (Helmand) River is one of the main challenges for water resources management in Iran and Afghanistan. This research aims to quantify the causes of this problem which has a direct impact on the dryness of the Hamoun wetlands being an international Ramsar site. To achieve this, the land use changes in the Middle Helmand Basin (MHB) in Afghanistan were evaluated for three time periods between 1990 and 2011 using remote sensing data and the Soil and Water Assessment Tool (SWAT) Model for understanding watershed response to environmental changes. It was concluded that the total irrigated area in the region has increased from 103,000 ha in

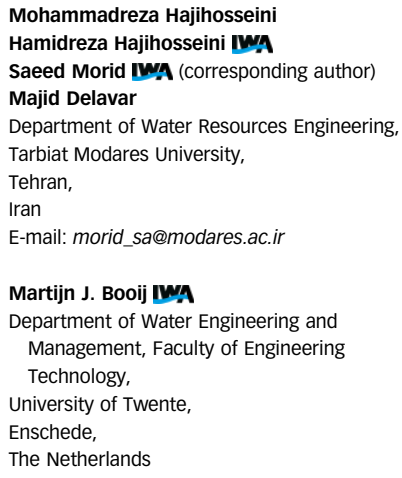
1990 to 122,000 ha in 2001 and 167,000 ha in 2011 (62\% increase). According to the results, the average annual discharge when adapting the land use during the simulations was 4,787 million cubic meters (MCM)/year and while employing the land use of 1990 from the beginning of the simulations, the average annual discharge was 5,133 MCM/year. Therefore, the agricultural developments in the Helmand basin decreased the discharge with about $346 \mathrm{MCM} /$ year accompanying an increase of 64,000 ha in an irrigated area in MHB after 1990. Notably, the impact of land use change increases significantly for more recent periods and causes a reduction of $810 \mathrm{MCM}$ in annual streamflow for the MHB. The amount of water depletion (i.e. actual evapotranspiration) per hectare has increased from 5,690 in 1985 to $7,320 \mathrm{~m}^{3}$ in 2012. The applied methodology of this study is useful to cope with such a data scarcity region. It can help quantify the impact of land use change on the region and formulates strategies that can improve the situation between Iran and Afghanistan.

Key words | climate variability, CRU data, international Hamoun wetlands, land use changes, SWAT model, transboundary Hirmand (Helmand) River

\section{INTRODUCTION}

Many river basins are facing a reduction in flows which might be attributed to climate change and human activities. The distinction between these two factors has received widespread attention, particularly in recent literature (Zhi et al. 2009; Yang et al. 20Io; Marhaento et al. 20I7a, 20I7b; Yin et al. 20I7). The importance of such analyses relates to doi: $10.2166 /$ wcc. 2019.100 their role in effective planning, management and sustainable development of water resources (Shi et al. 20I3; Khoi \& Suetsugi 20I4). This issue is very important in transboundary river basins, where already existing conflicts about shared water resources between riparian countries can easily escalate (Stefano et al. 2009). 
The Hirmand (Helmand) River basin in Iran and Afghanistan is an example of a transboundary river basin facing a decline in streamflow in recent decades. The river is the most important water resource shared between Iran and Afghanistan and plays an important role in the society and economy of this region. However, fast agricultural developments (UNODC 20I6) and changes in climatic variables (Vining \& Vecchia 2007; Vuyovich \& Jacobs 20II) in the basin are threatening the region's ecological stability. Reduction of Hirmand River flows (Hajihoseini et al. 20I6), as input to the Hamoun wetlands being an international Ramsar site (UNEP 2006), is serious evidence in this regard. There are several methods to understand and distinguish the contributions of climate change and human activities to the long-term change in streamflow (Mango et al. 20II; Khoi \& Suetsugi 2014; Wang 2014; Li et al. 2016). They can be categorized as (a) application of climate elasticity that expresses the rate of streamflow change with respect to precipitation and potential evapotranspiration changes (Zhi et al. 2009; Dong et al. 2012), (b) application of data-driven models like Artificial Neural Networks (Huo et al. 2008) and (c) application of conceptual models (Ye et al. 2013; Yin et al. 20I7). Among these methods, application of conceptual (Tomer \& Schilling 2009; Wang 20I4; Marhaento et al. $2017 \mathrm{~b})$ and physically based models gives more realistic insight into the changes (Wang 2014), since these enable simulations of the basin under historical and recent land use distributions as well as under historic and detrended climate data to analyze the respective impacts (Tomer \& Schilling 2009; Wang 20I4; Marhaento et al. 2017b).

Conceptual models have also been applied to transboundary basins. The research of Hongming et al. (2008) (for the Elbe basin, a transboundary basin flowing from the Czech Republic through Germany into the North Sea), Mango et al. (20II) (for the transboundary Mara River basin that is shared between Kenya and Tanzania) and Griensven et al. (2012) (in the upper Nile basin) are some examples. Among the applied models, the Soil and Water Assessment Tool (SWAT) has shown promising results for understanding watershed response to environmental changes (Mango et al. 20Iः; Griensven et al. 2012; Marhaento et al. 20I7b). On the other hand, SWAT and similar models need long-term time series of climate and hydrological data, while data collection and exchange are usually a serious obstacle in many transboundary basins due to political issues (Bitew \& Gebremichael 20II). Moreover, Afghanistan has remained largely undeveloped due to the unstable situation in recent decades. Thus, its infrastructure is still poor and the available data are also very limited (Hajihoseini et al. 2016). For such a situation, the application of global climate databases and remote sensing data to create land use maps and produce the required inputs of the hydrological models can be a useful solution (Mango et al. 20II). The global database of the Climate Research Unit (CRU) has been often considered in this regard, as it has the advantage of using a considerable number of ground observing stations (Harris et al. 20I3) and has a long record length. Notably, the combination of SWAT and CRU has been applied for a number of hydrological modeling studies in large basins (e.g. Abbaspour et al. 20Iо; Xu et al. 20I; Khoi \& Hang 20I5). Therefore, it can be a relevant option for the present study. This paper aims to study the impacts of climate variability and land use changes on streamflow of the Hirmand River during the period 1985 till 2012. Such evaluations are essential to identify the necessary bilateral policies between Iran and Afghanistan to manage the basin more cooperatively and especially, for the restoration of the international Hamoun wetlands (Ramsar site). Moreover, this period is a distinctive period in Afghanistan including many political events that have affected its development and consequently its water demand. One of the novelties of this paper is the development of a methodology to respond to the research questions of a transboundary river basin in a data-scarce region, while using data-intensive models like SWAT. Moreover, the results of this research provide information that decision-makers need in order to manage the basin and especially, save the Hamoun international wetlands.

\section{MATERIAL AND METHODS}

\section{Study area}

The transboundary Helmand basin is shared between Iran and Afghanistan. It includes a few principal tributaries originating from the south and westerly slopes of the Hindu Kush Mountains near Kabul and flows approximately $1,100 \mathrm{~km}$ from its source to the international Hamoun 
wetlands at the Afghan-Iranian border. Lake Hamoun is a seasonal lake and water is generally only present during the spring melt season (Mojtahed-Zadeh 2006; USGS 2016: https://earthshots.usgs.gov/earthshots/node/59). The average annual precipitation in the Helmand basin varies from 100 to $400 \mathrm{~mm}$ (NCDC 20I0).

The focus of this study is on the Transboundary Hirmand River (the main tributary) with a total surface area of $90,000 \mathrm{~km}^{2}$. The main agricultural activities can be found in the Middle Helmand Basin (MHB) and the main source of streamflow can be found in the Upper Helmand Basin (UHB). The Kajakai dam is located at the end of UHB. It is the only constructed dam in the Helmand River basin. This embankment dam is $90 \mathrm{~m}$ high with an uncontrolled open channel spillway and was constructed in the early 1950s to provide river control and irrigation benefits (Louis Berger Group Inc. 2004).

There is another tributary, the Arghandab River that joins the main stream at Qala-Bust in MHB. However, its importance for the total inflow to MHB is small due to irrigation consumption before reaching the Hirmand River (Helmand River Delta Commission I95I; Williams-Sether 2008). Figure 1 shows the discretization of the basin in this study.

\section{Data used}

For hydrological modeling of the Helmand basin, different data were needed including (1) observed hydrological data, (2) global climate databases, (3) land use and land cover information (4) operation rules of the Kajakai dam, (5) a Digital Elevation Model (DEM) and (6) a soil map and soil properties (e.g. particle size distribution, bulk density, organic carbon content and available water capacity). Table 1 shows the data used in this study and related references. Part of the required information needed some prepreprocessing that is explained in the next sections.

\section{CRU database}

The CRU data were used in this study. The applied version is TS v3.21 (2013) (http://www.cru.uea.ac.uk/), which contains several climate variables. The monthly CRU data were converted to a daily time step - necessary for SWAT input - using the daily weather generator algorithm 'dGen'
(Geng et al. 1986). This algorithm has been applied in similar studies as well (e.g. Schuol \& Abbaspour 2006; Schuol et al. 2008). The CRU precipitation data were evaluated using the observed data. For this, the mean annual precipitation map of the entire basin (for the period 1961-1976) was produced using the CRU dataset and the available recorded data of meteorological stations. Over $250 \mathrm{CRU}$ grid cells and 15 stations in Afghanistan, 2 in Iran and 1 in Pakistan were used to construct the maps using the Kriging interpolation method that performed better than other spatial interpolation methods. None of the meteorological stations is located in MHB.

\section{Land use and land cover information}

Land use information is required to build the model input for SWAT. Three land use maps were constructed for this study using Landsat TM and ETM+ satellite imagery (30 meter resolution) dated 29 May 1990, 05 March 2001 and 05 July 2011, along with images in April and September that were obtained from websites of the United States Geological Survey (USGS), United States space agency (NASA), Global Land Cover Facility and Landsat website archive (see Table 1). To aid the analysis of images, complimentary information was collected including (1) the type of land use and land cover from the Afghanistan Information Management System (AIMS) in 1990 and 2000 at a scale of 1:250,000 (Favre \& Kamal 2004), (2) a land cover map of the World Food Organization (FAO I995), (3) a map of the early warning and environmental monitoring program of the USGS and (4) Google Earth images of May 2011, October 2013 and April 2002.

\section{Methodology}

\section{Climate variability}

To evaluate climate variability, the non-parametric MannKendall (MK) and Mann-Whitney (MW) tests were selected, which are widely applied to detect monotonic trends and important changes (Partal \& Kahya 2006; Kendall 1975, Mann r945). Additionally, the non-parametric Pettitt's test method was used to detect a significant change in the mean of a time series (Zhang et al. 20II). 


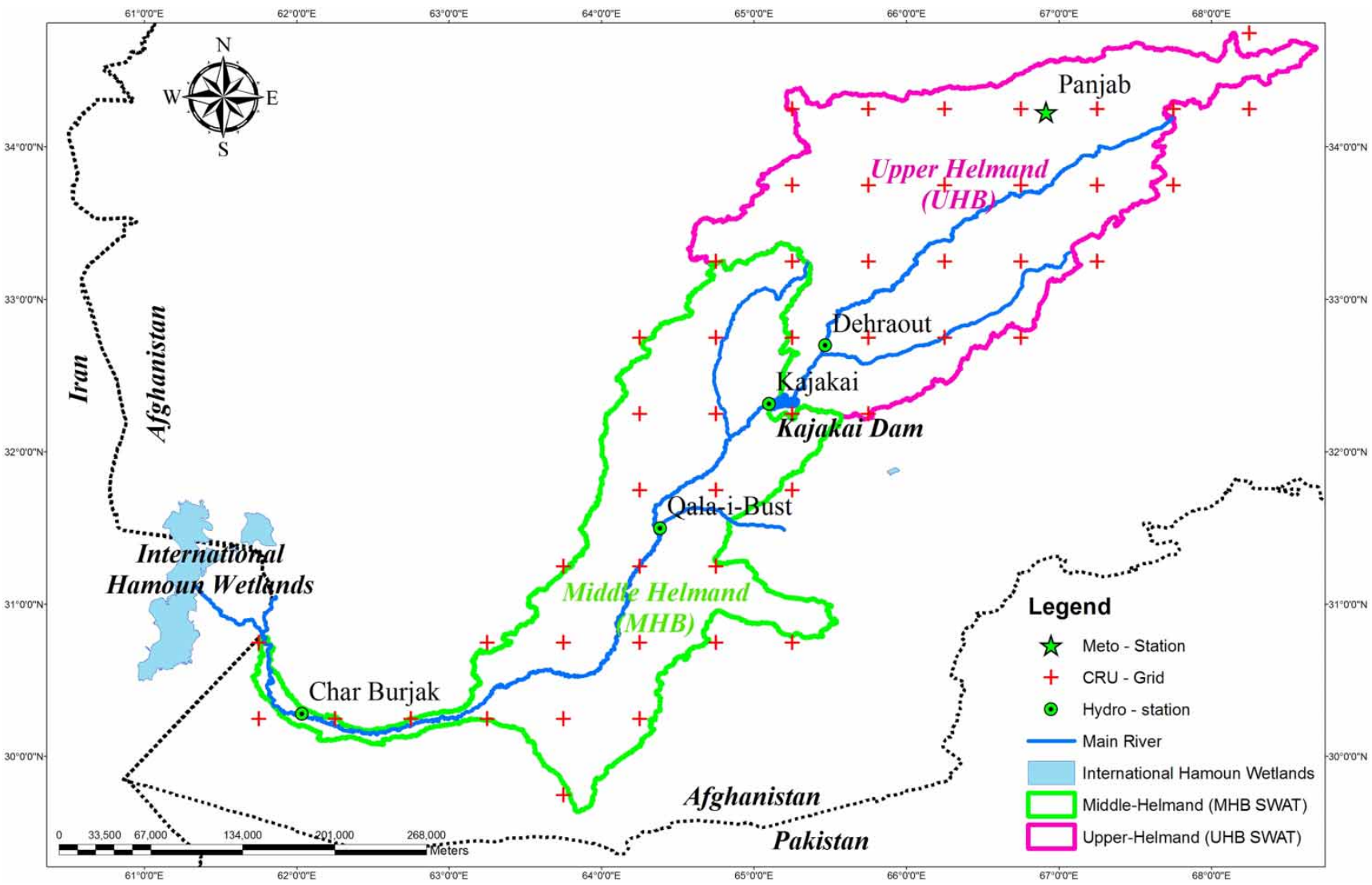

Figure 1 | Location of the Transboundary Hirmand (Helmand) River.

Table 1 | Information and data used in SWAT model

MHB data

(1) Observed climatological data

Hydrological data

(2) Global Climate Databases

(3) Land use/land cover information

(4) Operation of Kajakai dam

(5) Digital elevation model (DEM)

(6) Soil map and soil properties

References

Period

- NOAA Central Library (http://docs.lib.noaa.gov)

- Afghanistan Peace Project (http://cmit.tamu.edu)

- World Meteorological Organization (http://www.wmo.int)

USGS Afghanistan Project (Williams-Sether 2008):

- Dehraout discharge station

- Qala-i-Bust station located on the Drain of Arghandab River

- Char-Burjak discharge station as the outlet of the Helmand River

- Climate Research Unit (CRU) (http://www.cru.uea.ac.uk/)

- Landsat TM and ETM+ satellite imagery

- inflows and outflows of the Kajakai dam (Vining \& Vecchia 2007; Williams-Sether 2008)

- simulated time series Dehraout station (Hajihoseini et al. 2016)

- NASA Shuttle Radar Topographic Mission (SRTM)

- Map of the Food and Agriculture Organization of the United Nations
Prior to 1979

Monthly time series

1953-1979

1953-1979

1969-1985

1948-2012

$1973,1985,1990,1993,1998$, 2001, 2009, 2011 a , 2013

Monthly time series

1957-1979

1979-2016

2000

1995

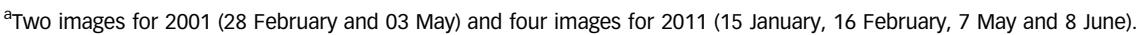




\section{Land use classification}

Using the Landsat remote sensing data, the respective images were classified using a number of methods including maximum-likelihood classification (MLC), decision trees (DT) and support vector machine (SVM) algorithms (Otukei \& Blaschke 2010). MLC is a well-known parametric supervised classification approach that has been widely used in remote sensing applications with promising reports about its performance (Manandhar et al. 2009). DT is a non-parametric classifier with good results in the literature (e.g. Mahesh \& Mather 2003). SVM is also a data-driven approach based on machine learning theory (Vapnik 1999) to separate complex classes (Huang et al. 2002). In addition, Knorn et al. (2009) suggested that SVM is relevant for land cover classification for large areas with minimal requirements for image pre-processing and training data. For the purpose of this study, a total of six land cover classes were considered. They are: (a) irrigated agricultural lands, (b) rainfed agricultural lands, (c) dense pasture lands, (d) poor pasture lands (barren and rocky), (e) water and (f) water straw lands (e.g. marshes and wetland).

Furthermore, an accuracy assessment was performed on the resulting classified imageries. This process involves generating a set of points in the classified imagery and comparing them with actual points on the ground through fieldwork. For this, 55 points for all land cover classes were collected from Google Earth and other sources. The land cover classification assigned to each pixel was then compared with the same location on the reference sources to see if the classification result was accurate. Although no real standard for accuracy has been established by the remote sensing community, $80 \%$ accuracy is considered acceptable (Congalton \& Green 1999). General accuracy of these algorithms was assessed with the Kappa coefficient, user accuracy and producer accuracy which were generated from an error matrix (Congalton I99I).

\section{SWAT model}

SWAT is a semi-distributed hydrological model that can be applied at the river basin scale to simulate the impact of land management practices on water, sediment and agrochemical yields in river basins with varying soil types, land use and agricultural conditions over extended periods of time (Arnold et al. 1998). The model makes it possible to simulate ungauged basins and more importantly simulate the impact of alternative input data, such as changes in land use, land management practices and climate (Arnold et al. 1998; Neitsch et al. 2005), which is crucial for the objectives of this study. The simulation of the hydrologic cycle in the model is based on the water balance equation. In SWAT, a basin is divided into sub-basins, which are then further subdivided into hydrologic response units (HRUs) which consist of units with homogeneous topographical, land use and soil characteristics. Further technical details about the model are given by Neitsch et al. (2005).

After preparing the required climate and spatial data as well as creating the land use maps, the next step was to discretize the Helmand basin into sub-basins and to determine the number of HRUs. Combination of the soil, land use and slope/topography maps resulted in 7 sub-basins and 73 HRUs for MHB.

Furthermore, sensitivity analysis of parameters, calibration, validation and uncertainty analysis of the model was done using the SWAT-CUP tool (Abbaspour 2007). The tool includes a number of methods for calibration and the Sequential Uncertainty Fitting Algorithm was applied here. In the sensitivity analysis, 23 parameters which relate to various hydrological components (e.g. soil, reach, groundwater, surface runoff and snow) were evaluated. The results showed that IRR_MX [amount of irrigation water applied each time auto irrigation is triggered (mm)], IRR_ASQ (surface runoff ratio) and SOL_AWC [available water capacity of first soil layer $(\mathrm{mm} / \mathrm{mm})$ ] were the most sensitive parameters.

For irrigation and fertilization management, we selected the default option because of the difficulty in obtaining the respective data for this region. This has been done in a similar way for many other studies dealing with large-scale and transboundary basins (e.g. Liu et al. 2007; Zhi et al. 2009; Yong et al. 2017).

Figure 2 illustrates the aforementioned data sources and tools and their interrelationships to address the objectives of this research work. The figure consists of four main components: (1) processing of the global climate data (the monthly CRU data were converted to a daily time step with the daily weather generator algorithm 'dGen' and the CRU precipitation data were evaluated using observed data), (2) 


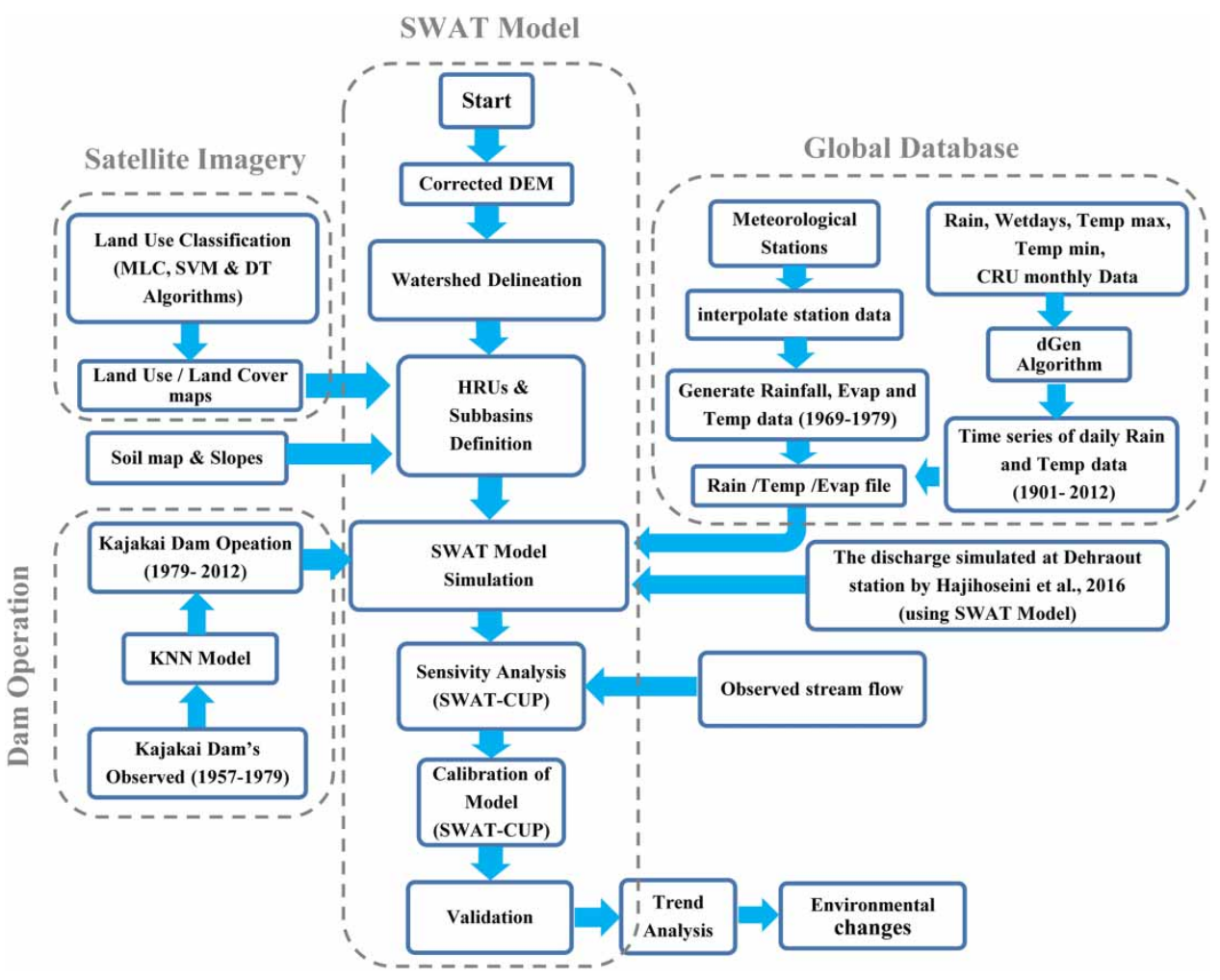

Figure 2 | Flow chart of the modeling process, input and outputs.

creation of land use maps (MLC, DT and SVM algorithms), (3) simulation of dam operation (the K Nearest Neighbor model (KNN) was applied for the estimation of the Kajakai Dam Operation Program) and (4) application of the SWAT model. These components are explained in detail in the 'CRU database', 'Land use classification', 'Simulation of Kajakai dam operation' and 'SWAT model' sections, respectively.

\section{RESULT AND DISCUSSION}

\section{Climate data analysis}

The resulting maps of annual precipitation are shown in Figure 3 and reveal a reasonable performance of the CRU dataset. For the entire Helmand basin, the observed annual mean precipitation is $225 \mathrm{~mm}$ using meteorological stations and $197 \mathrm{~mm}$ using the CRU dataset. These amounts are 190 and $228 \mathrm{~mm}$ for MHB, respectively. The monthly mean precipitation for the MHB basin using these two sources of data shows very consistent results (Figure 4).
For the temperature, due to the limited number of available records and also less spatial variation compared with precipitation, the assessment was solely done for Panjab station, which is located in UHB (Figure 1). It is also reported that CRU temperatures usually fit better with observations than other datasets (Döll et al. 2003). Figure 5 shows the average mean, maximum and minimum monthly observed and CRU temperature.

\section{Simulation of Kajakai dam operation}

As shown in Figure 1, the main inflow to MHB is the release of flow from Kajakai dam. The only available records for the dam's inflow (i.e. Dehraout station) and outflow are for the period 1957-1979. This information was used to extract the dam operation rules. For this, the $\mathrm{K}$ Nearest Neighbor model (KNN) (Karlsson \& Yakowitz 1987) was applied, 75\% of the records were randomly considered for training and $25 \%$ for validation of the model. To find the best neighborhoods in the KNN model, a Euclidean function is the most common one to use. The Euclidean function is defined 


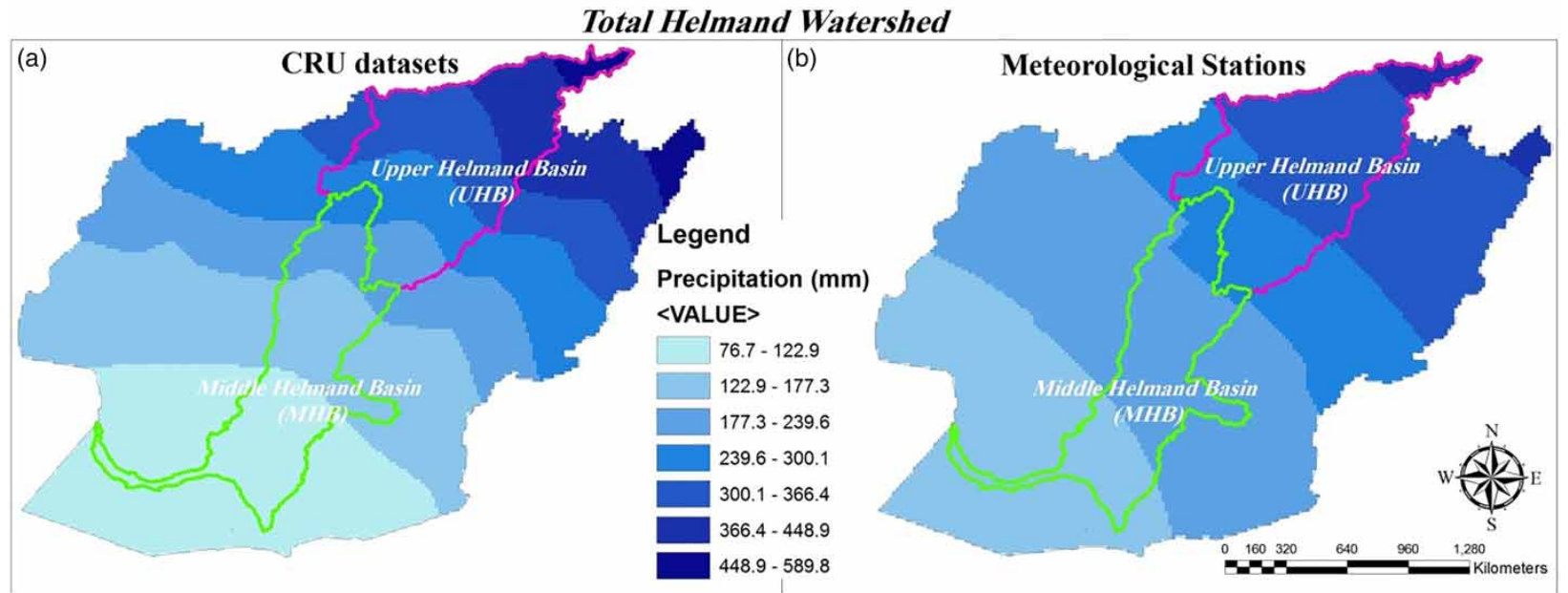

Figure 3 Map of annual mean precipitation in the Helmand basin using (a) CRU dataset and (b) meteorological stations for the period 1961-1976.

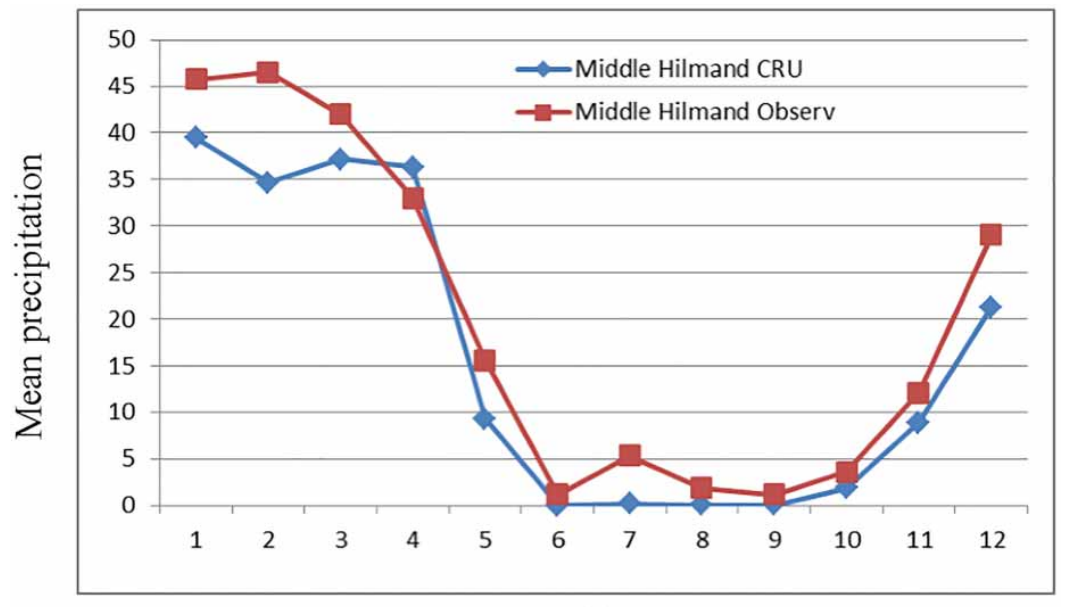

Monthly

Figure 4 | Monthly mean precipitation in the Middle Helmand basin using the CRU dataset and meteorological stations for the period $1961-1976$.

based on the distance between two points in the Euclidean space. Considering a variety of neighborhoods, a neighbor number of 5 and Euclidean distance was chosen. Finally, the selected inputs of the KNN model were the current discharge $Q_{\text {in }}(t)$ and the discharges in the previous three months $\left[Q_{\text {in }}(t-\right.$ $1), Q_{\text {in }}(\mathrm{t}-2)$ and $\left.Q_{\text {in }}(\mathrm{t}-3)\right]$ at Dehraout station (Figure 6).

This resulted in the best performance to simulate the releases of the dam $\left[Q_{\text {out }}(\mathrm{t})\right]$ with a correlation coefficient of $72 \%$. Using the KNN model and simulated time series at Dehraout station from 1979 to 2012 based on the previous work of the authors (Hajihoseini et al. 2016), the Kajakai dam outflows were simulated for this period as shown in Figure 7. The figure shows that high inflows are stored in the reservoir during the wet season and low inflows are supplemented by additional releases of the reservoir.

\section{Simulation of streamflow}

\section{SWAT model calibration and validation}

The model calibration was performed using the available observed discharge data at Char-Burjak station and different global datasets. The land use of 1990 was applied for the calibration period, because it could be assumed that due to the 


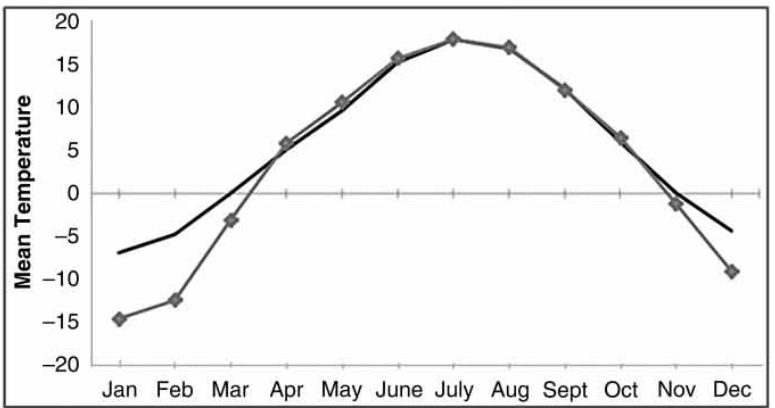

\section{Monthly Average Temperature $\left({ }^{\circ} \mathrm{C}\right)$}

- CRU

$\curvearrowright$ Observation (Panjab)
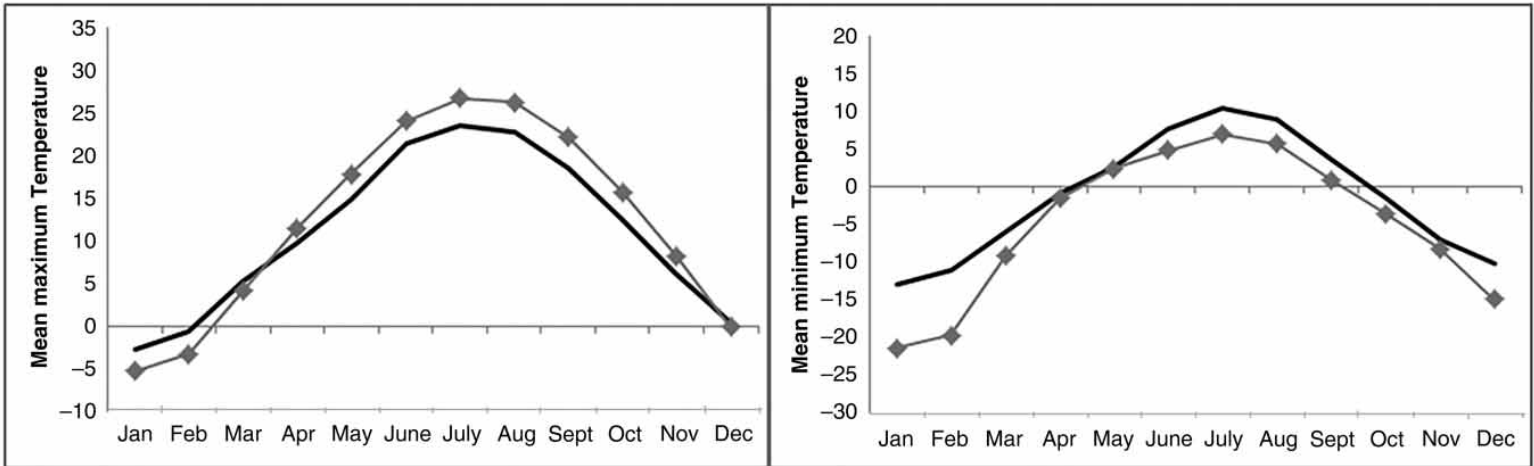

Figure 5 | Monthly average mean, maximum and minimum temperature in the Helmand basin using the CRU dataset and meteorological station Panjab for the period 1965-1977.

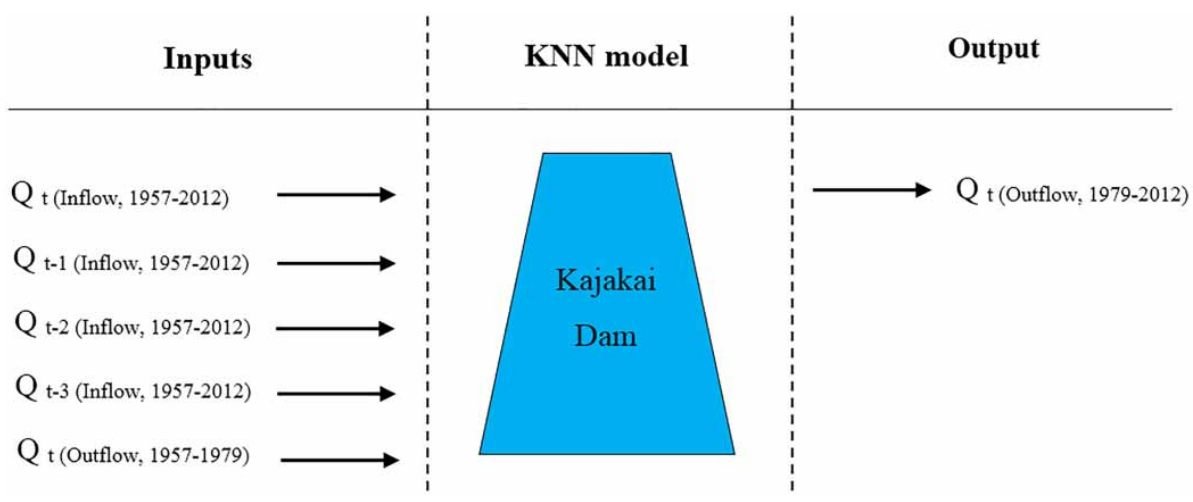

Figure 6 | Process for estimation of the Kajakai Dam Operation Program using the KNN model.

civil war and no state situation in Afghanistan before 2001, no significant development has occurred between 1990 and 2001.

In order to calibrate and validate parameters for $\mathrm{MHB}$, monthly available streamflow records from the period 1968 to 1978 were split into two segments. The first four years were used to calibrate and the rest to validate. The results were satisfactory with $R^{2}$ and NS values of 0.67 and 0.67 for the calibration and 0.65 and 0.63 for the validation, respectively. Figure 8 shows the observed and simulated streamflow for this period at Char-Burjak station.
Hydrological responses to climate variability and land use changes

In this section, it is aimed to separately evaluate impacts of climate variability and land use changes on the Hirmand streamflow. However, since the most significant changes in the climate variables and land use have occurred since 1985, the evaluation was only carried out for this period. To calculate the relative influence of climate variability versus land use change on streamflow in the SWAT model, we changed one factor at a time while holding the others constant 


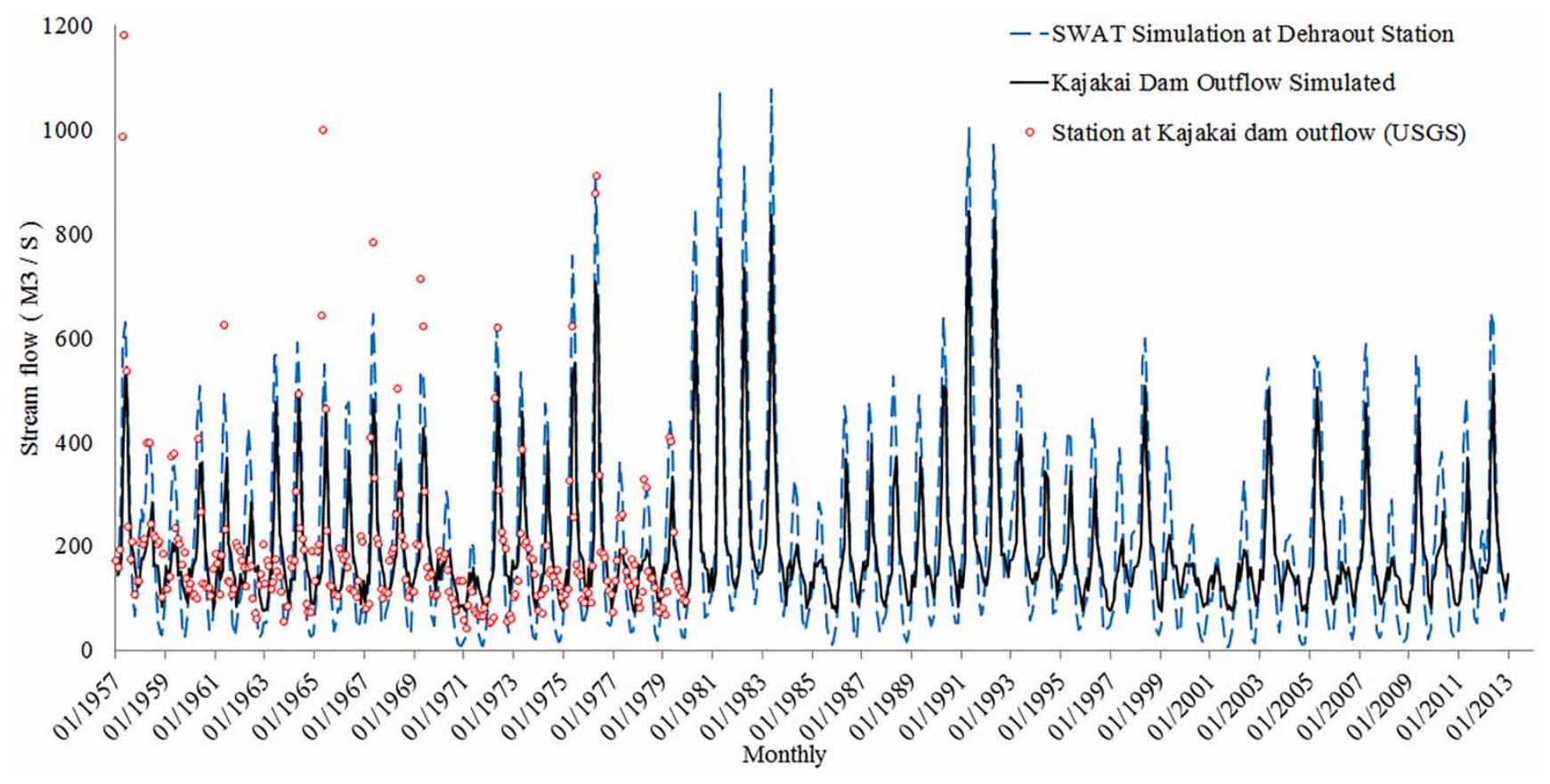

Figure 7 | Simulated time series of inflows to Kajakai reservoir and outflows of Kajakai reservoir simulated using the KNN model.

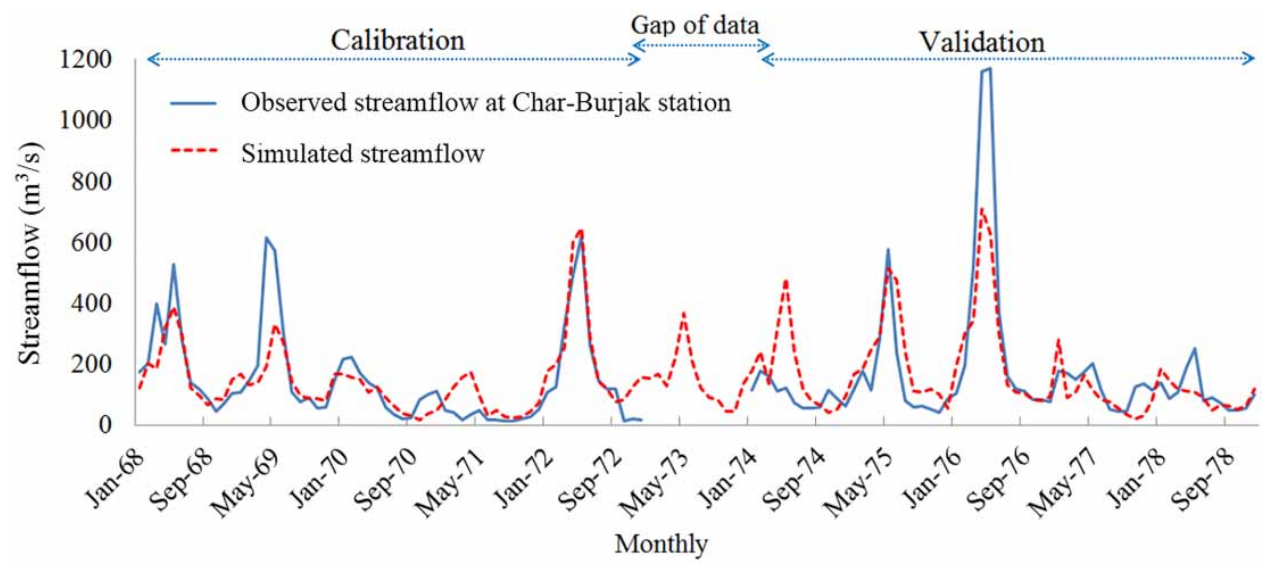

Figure 8 | Comparison of observed and simulated stream flow at Char-Burjak station during the calibration and validation periods.

(Zhang et al. 20II; Khoi \& Suetsugi 20I4; Li et al. 2016). We ran the following four scenarios and compared their outputs.

Scenario 1: Climate data during the baseline period (for the 1985-2012 period with the detrended temperature) and land use data during the baseline period (land use in 1990): baseline.

Scenario 2: Climate data during the study period (for the 1985-2012 period) and land use data during the baseline period (land use in 1990): climate variability.
Scenario 3: Climate data during the baseline period (for the 1985-2012 period with the detrended temperature) and land use data during the study period (land use in 1990, 2001 and 2011): land use change.

Scenario 4: Climate data during the study period (for the 1985-2012 period) and land use data during the study period (land use in 1990, 2001, 2011): climate variability and land use change. 
The difference in outputs between scenarios S2 (S3) and S1 indicates the impact of climate variability (land use change) on streamflow in SWAT. The formula for determining the impact is as follows:

$\Delta R_{\text {Climate }}=R_{\mathrm{S} 2}-R_{\mathrm{S} 1}$

$\Delta R_{\text {Landuse }}=R_{\mathrm{S} 3}-R_{\mathrm{S} 1}$

$\Delta R_{\text {Total }}=\Delta R_{\text {Climate }}+\Delta R_{\text {Landuse }}$

where $R_{\mathrm{S} 1}, R_{\mathrm{S} 2}$ and $R_{\mathrm{S} 3}$ are the average runoff from scenarios

Table 2 | Mann-Kendall statistical values for the annual minimum temperature

\begin{tabular}{llllll} 
CRU grid code & $\boldsymbol{N}$ & Period & & Z-statistical & Significance level \\
\hline a254 & 72 & 1941 & 2012 & 6.87 & a \\
a279 & 72 & 1941 & 2012 & 6.93 & a \\
a280 & 72 & 1941 & 2012 & 6.97 & a \\
a301 & 72 & 1941 & 2012 & 6.01 & a \\
a302 & 72 & 1941 & 2012 & 6.42 & a \\
a303 & 72 & 1941 & 2012 & 6.71 & a \\
a324 & 72 & 1941 & 2012 & 4.94 & a \\
a326 & 72 & 1941 & 2012 & 5.90 & a \\
a327 & 72 & 1941 & 2012 & 6.32 & a \\
a348 & 72 & 1941 & 2012 & 4.38 & a \\
a373 & 72 & 1941 & 2012 & 4.28 & a \\
a396 & 72 & 1941 & 2012 & 2.95 & b \\
\hline
\end{tabular}

${ }^{\mathrm{a}} \alpha=0.001,{ }^{\mathrm{b}}: \alpha=0.01$
$\mathrm{S} 1, \mathrm{~S} 2$ and $\mathrm{S} 3$, respectively; $\Delta R_{\text {Climate }}\left(\Delta R_{\text {Landuse }}\right)$ is the difference in SWAT output between scenarios S2 (S3) and S1.

\section{Scenario 2: Response to climate variability}

In order to study changes in discharge time series due to climate variability, possible trends in the climate data were evaluated using the Mann-Kendall test. The results showed that there is no significant trend in climate variables except for the minimum temperature (Table 2).

Furthermore, the Pettitt test was applied and detected meaningful changes in 1976. The time series of minimum temperature is detrended using the method suggested by Hamlet \& Lettenmaier (2007) and the SWAT input files were modified accordingly. While the recorded average annual minimum temperature was $1.5^{\circ} \mathrm{C}$ (1941-2012), its detrended value reduces to $0.9{ }^{\circ} \mathrm{C}$. In Figure 9, we compare the minimum temperature of the CRU grid at one of the CRU grid (a 254).

Applying the detrended time series of monthly minimum temperature, the calibrated SWAT model was used to simulate discharges at Char-Burjak station. The discharge time series based on detrended climate data and the discharge time series based on observed climate data (without detrending) are shown in Figure 10. It can be seen that the differences are not very significant. For instance, the annual mean discharges are 4,733 MCM and 4,787 MCM, respectively.

\section{Scenario 3: Response to land use change}

The results in the accuracy assessment of the land use classification showed a Kappa coefficient value between $72 \%$ and 93\%, while the overall classification accuracy was between

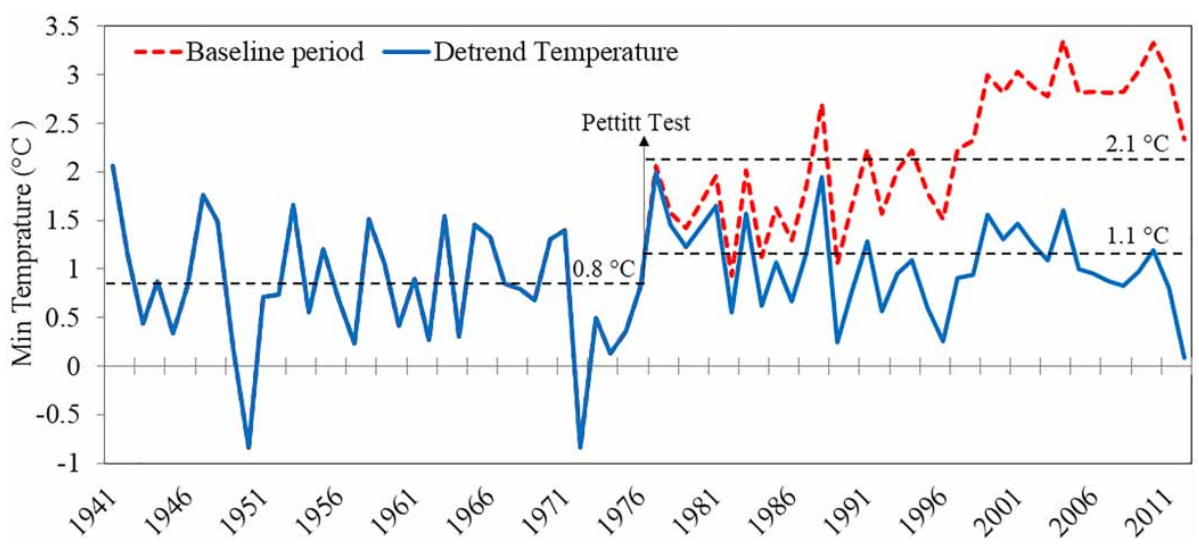

Figure 9 | Comparison of the minimum temperature of the CRU grid (baseline period vs. detrended temperature). 


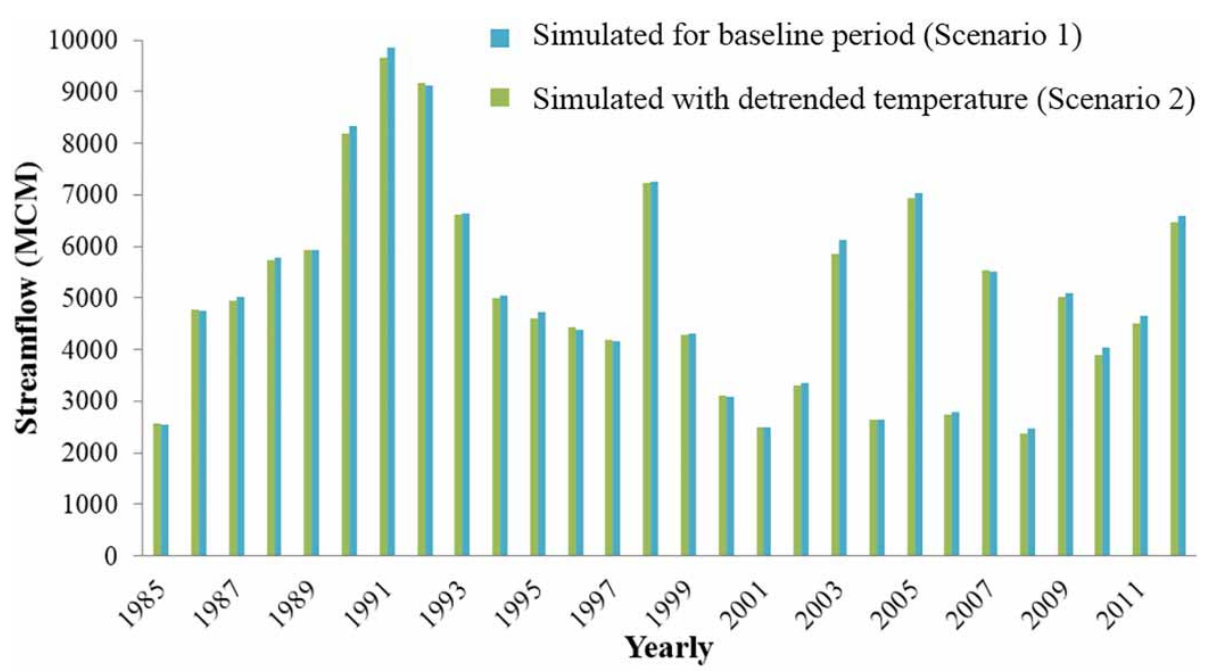

Figure 10 | Comparison of simulated annual discharge of Hirmand River at Char-Burjak station using the original time series of minimum temperature and the detrended time series.

$82 \%$ and 90\%. Congalton \& Green (I999) suggest that the values above $80 \%$ are acceptable. Using the processed images, the changes in land use from 1990 to 2011 were determined and the results can be found in Table 3 .

To describe the changes, three main agricultural regions in MHB are discussed below.

\section{Nawa Barakzai area (West Lashgargah city)}

As Figure 11 indicates, the majority of marshland (swamp and wetland), located at the downstream end of the Boughra Creek, has dried up after 1990 and converted into irrigated lands of which their total area has increased from 11,909 ha in 1990 to 24,454 ha in 2011 .

\section{Nowzad area}

Comparing the results in Table 3, it can be seen that the rainfed area has severely increased from 1990 to 2011, mostly in Musa Qala and Nowzad highlands. In this region, a sharp increase in the cultivated area is observed (Figure 12).

\section{Nad Ali area (West Boughra Creek)}

Increasing cultivation area (irrigated and rainfed) has also occurred in the upstream part of Boughra Creek. Groundwater (qanats and wells) is a source of water supply for the increased agricultural lands (Favre \& Kamal 2004) (see Figure 13).

Due to the above-mentioned changes, the total area of agricultural lands (irrigated and rainfed) was estimated to be 200,000 ha in 2011. Comparing the results of 1990 with 2001 shows that dense land had changed to bare land. Comparing the results of the classification of different periods (Table 3), it can be seen that the irrigated area has increased from 103,000 ha in 1990 to 122,000 ha in 2001 and then to 167,000 ha in 2011.

Table 3 | Area of different land cover classes for the three studied classification methods (in 1,000 ha) for three different years

\begin{tabular}{|c|c|c|c|c|c|c|c|}
\hline \multirow[b]{2}{*}{ Land use classes } & \multicolumn{3}{|c|}{ Selected methods } & \multicolumn{3}{|c|}{ Area used in SWAT (1,000 ha) } & \multirow{2}{*}{$\begin{array}{l}\text { Comparison 2011-1990 } \\
\text { Changes }(\%)\end{array}$} \\
\hline & 1990 & 2001 & 2011 & 1990 & 2001 & 2011 & \\
\hline Marshland (permanently inundated/seasonal) & SVM & SVM & SVM & 89.9 & 50.2 & 4.3 & $-95.2 \%$ \\
\hline Irrigated cultivated & SVM. DT & MLC & SVM. DT & 103.1 & 122.2 & 167.0 & $62.1 \%$ \\
\hline Rainfed crops & & SVM. DT & & 0.0 & 0.0 & 32.0 & $100 \%$ \\
\hline Water bodies & & SVM. DT. MLC & & 14.4 & 5.6 & 9.2 & $-36.5 \%$ \\
\hline Rangeland (grassland/forbs/low shrubs) & & SVM. DT. MLC & & 962.9 & 312.3 & 286.0 & $-70.3 \%$ \\
\hline Rock outcrop/bare soil & & SVM. DT. MLC & & 995.9 & $1,675.9$ & $1,667.7$ & $62.2 \%$ \\
\hline Total & & & & & $2,166.2$ & & \\
\hline
\end{tabular}




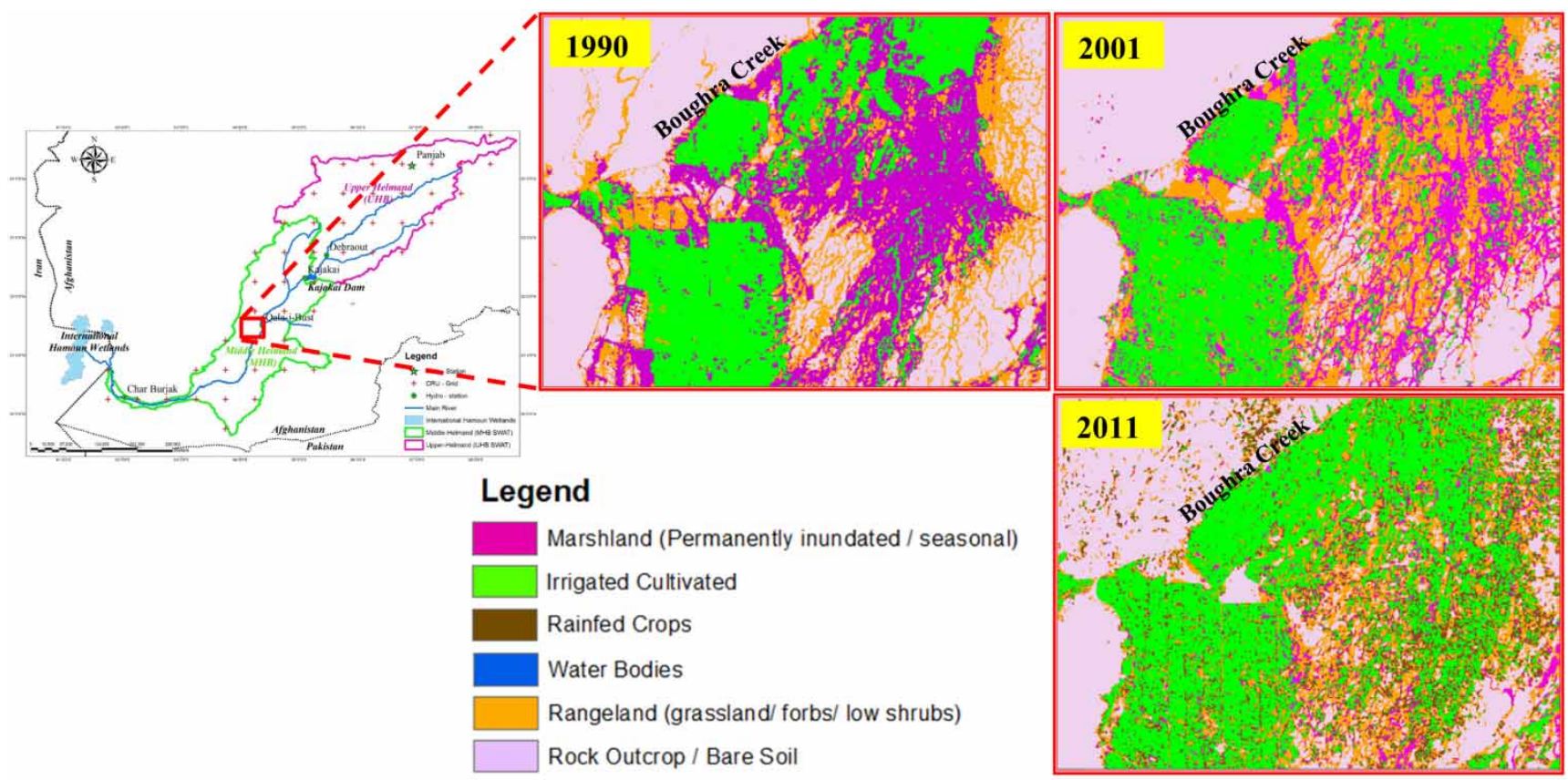

Figure 11 | Change in land use in the Nawa Barakzai region from 1990 to 2011.
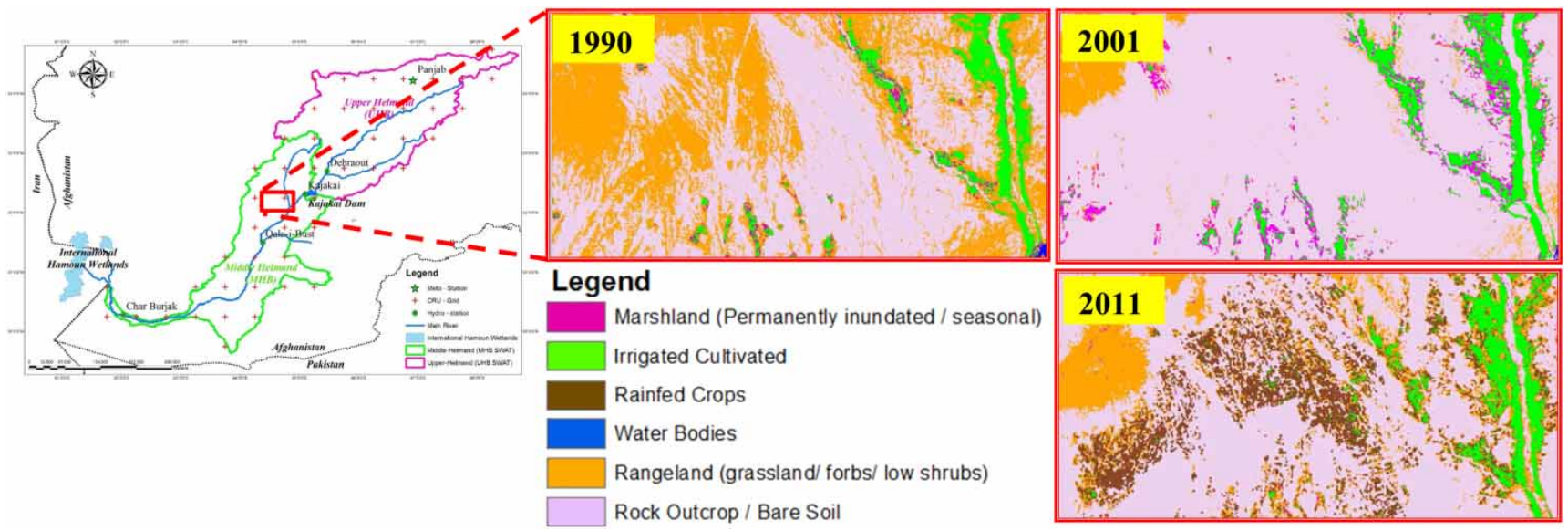

Figure 12 | Change in land use in the Nowzad region from 1990 to 2011.

The land use changes represent the impact of human activities in the basin. Similarly as in the previous section, the calibrated model was run with the three created land use distributions and the real recorded data (Figure 14). According to the results, the average annual discharge when changing the land use during the simulations was 4,787 MCM/year, while employing the land use of 1990 from the beginning of the simulations, the average annual discharge was 5,133 MCM/year. Therefore, the agricultural developments in the Helmand plain decreased the discharge with about $346 \mathrm{MCM} / \mathrm{year}$. The increase of 64,000 ha (Table 4) in an irrigated area in MHB after 1990 and the 346 MCM decrease in discharge correspond to $5,400 \mathrm{~m}^{3} / \mathrm{ha}$ of evapotranspiration. This amount is similar to amounts reported by FAO for the agricultural water consumption in the Hirmand River basin using satellite images and a water accounting method (FAO 2015). 


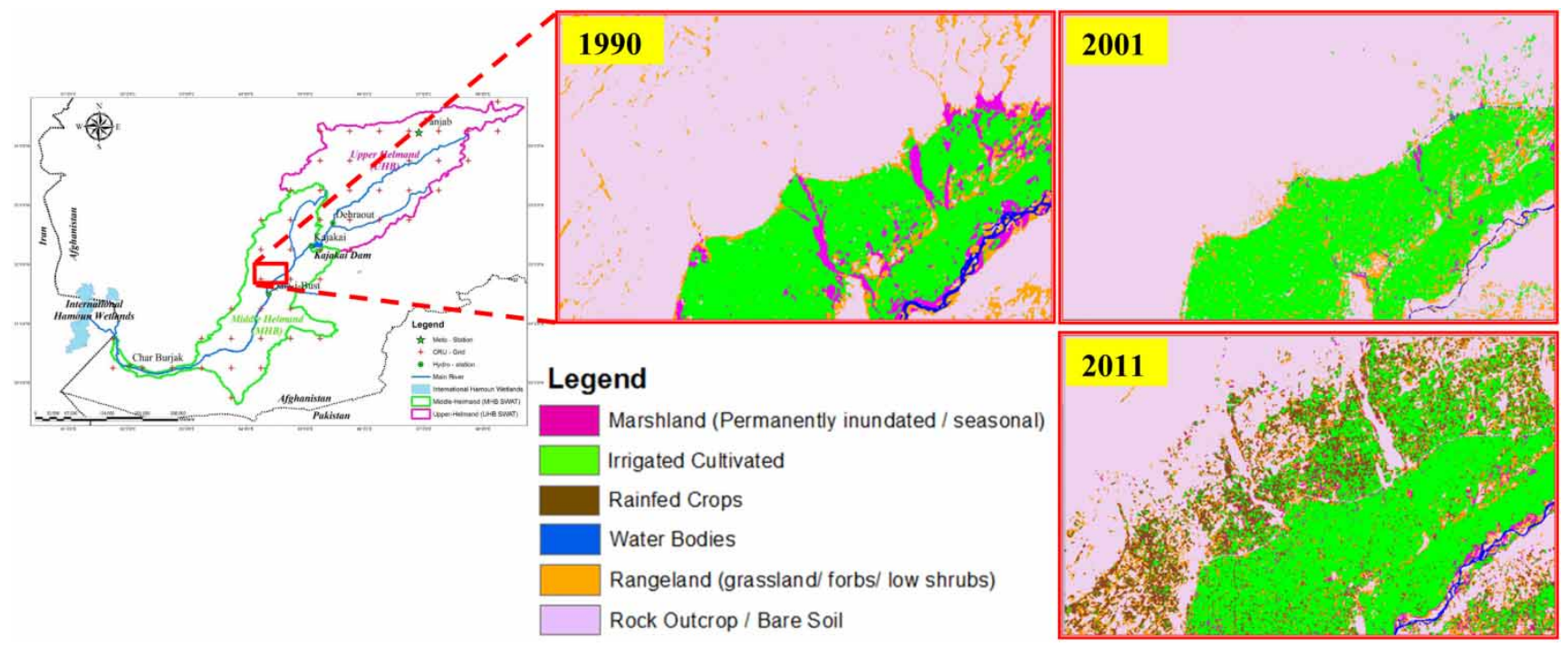

Figure 13 | Change in land use in the Nad Ali region from 1990 to 2011.

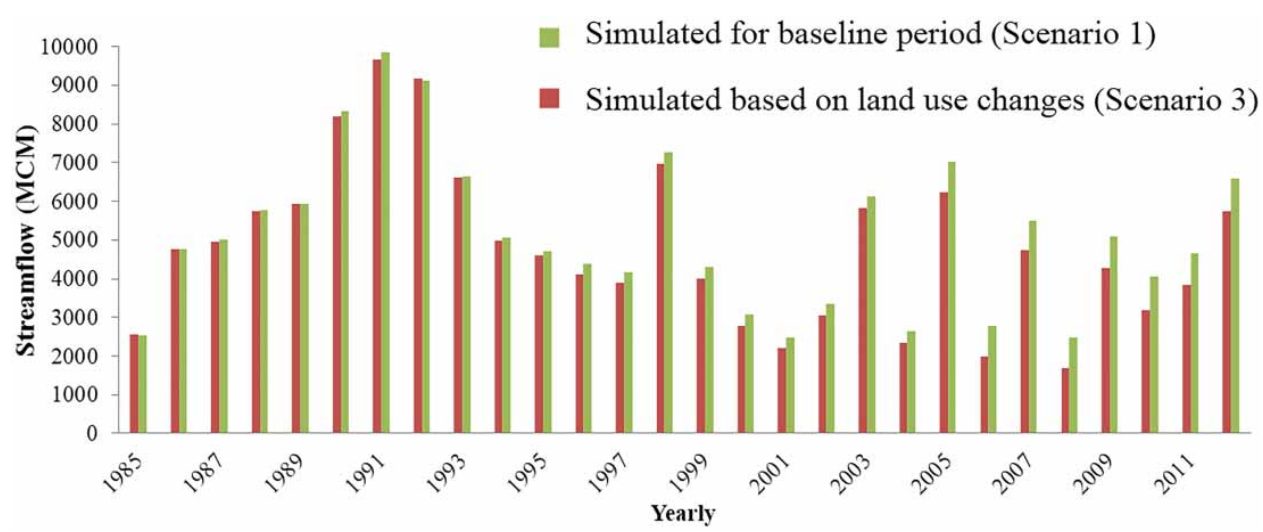

Figure 14 | Simulated annual discharge at Char-Burjak station using different land use distributions.

Table 4 | Relative impacts of climate variability and land use change on annual streamflow in the SWAT model

\begin{tabular}{|c|c|c|c|c|c|c|c|c|c|}
\hline \multirow{4}{*}{$\frac{\text { Periods }}{1985-1994}$} & \multicolumn{5}{|c|}{ Simulation streamflow at Char-Burjak station (MCM) } & & & & \\
\hline & \multirow{3}{*}{$\begin{array}{l}\text { sı } \\
\text { Baseline } \\
6,303\end{array}$} & \multirow{3}{*}{$\begin{array}{l}\text { S2 } \\
\text { Climate variability } \\
6,258\end{array}$} & \multirow{3}{*}{$\begin{array}{l}\text { s3 } \\
\text { Land use changes } \\
6,258\end{array}$} & \multirow{3}{*}{$\begin{array}{l}\text { s4 } \\
\text { climate and land use changes } \\
6,212\end{array}$} & \multirow{3}{*}{$\begin{array}{l}\Delta \boldsymbol{R}_{\text {Total }} \\
\Delta \boldsymbol{R}_{\text {climate }}+\Delta_{\text {Land use }} \\
91\end{array}$} & \multicolumn{4}{|c|}{ Relative proportion (\%) } \\
\hline & & & & & & \multicolumn{2}{|c|}{ Climate } & \multicolumn{2}{|c|}{ Land use } \\
\hline & & & & & & 45 & $50 \%$ & 45 & $50 \%$ \\
\hline 1995-2004 & 4,252 & 4,216 & 3,977 & 3,942 & 310 & 35 & $11 \%$ & 275 & $89 \%$ \\
\hline $2005-2012$ & 4,772 & 4,684 & 3,962 & 3,874 & 898 & 88 & $10 \%$ & 810 & $90 \%$ \\
\hline Average & 5,133 & 5,079 & 4,787 & 4,733 & 400 & 54 & $14 \%$ & 346 & $86 \%$ \\
\hline
\end{tabular}




\section{Scenario 4: Response to combined climate variability and land use changes}

For evaluation of the combined impacts of climate variability and land use changes, the calibrated model was run using the 1990, 2001 and 2011 land uses, global climate data and land use update option of the SWAT model to simulate the entire period from 1968 to 2012 . Figure 15 shows the simulated streamflow time series at Char-Burjak station. The reduction of streamflow is considerable in recent years and is discussed in the following section.

Table 4 shows that the relative impact of land use changes during the first period (1985-1994) was only 45 MCM. The climate variability has the same, small impact. Notably, the impact of land use change increases significantly for more recent periods and causes a reduction of $810 \mathrm{MCM}$ in annual streamflow for the MHB (i.e. outflow from Char-Burjak station).

Figure 16 focuses on the changes in actual evapotranspiration and streamflow in MHB. It can be seen that the actual evapotranspiration increased from $5,690 \mathrm{~m}^{3} /$ ha for the first period to $7,320 \mathrm{~m}^{3} / \mathrm{ha}$ in the second period. This means that the amount of actual evapotranspiration has increased by about $28 \%$. The reason for this drastic change can be explained by the research work of Zarezadeh et al. (2018). They applied monthly remotely sensed data for the entire Helmand basin and reported that the area of double cropping in Helmand has increased about 103\% from 1990 to 2013.

\section{CONCLUSIONS}

This study aimed to investigate the impacts of land use changes and climate variability on hydrological characteristics of the transboundary Helmand River. Data availability is a general problem for river basins in Afghanistan and this also applies for the MHB, as the study area of this research work, where considerable agricultural activities are going on. The following conclusions can be drawn for this study:

1. The combination of the global CRU dataset, Landsat images and the SWAT model provided a useful framework to overcome the serious data and information scarcity and inaccessibility in the study area.

2. The created land use distributions for MHB showed that the irrigated agricultural area has increased from 103,000 to 167,000 ha between 1990 and 2011. The main developments have occurred over Nawa Barakzai, Nowzad and Nad Ali (West Boughra Creek) areas. The changes are generally due to the conversion of rainfed land and wetlands to irrigated land after 2000.

3. Comparison of the simulations of the SWAT model with and without detrended climatic time series showed that the changes in streamflow are not very significant. According to the results, the average annual discharge with adapting the land use during the simulations was

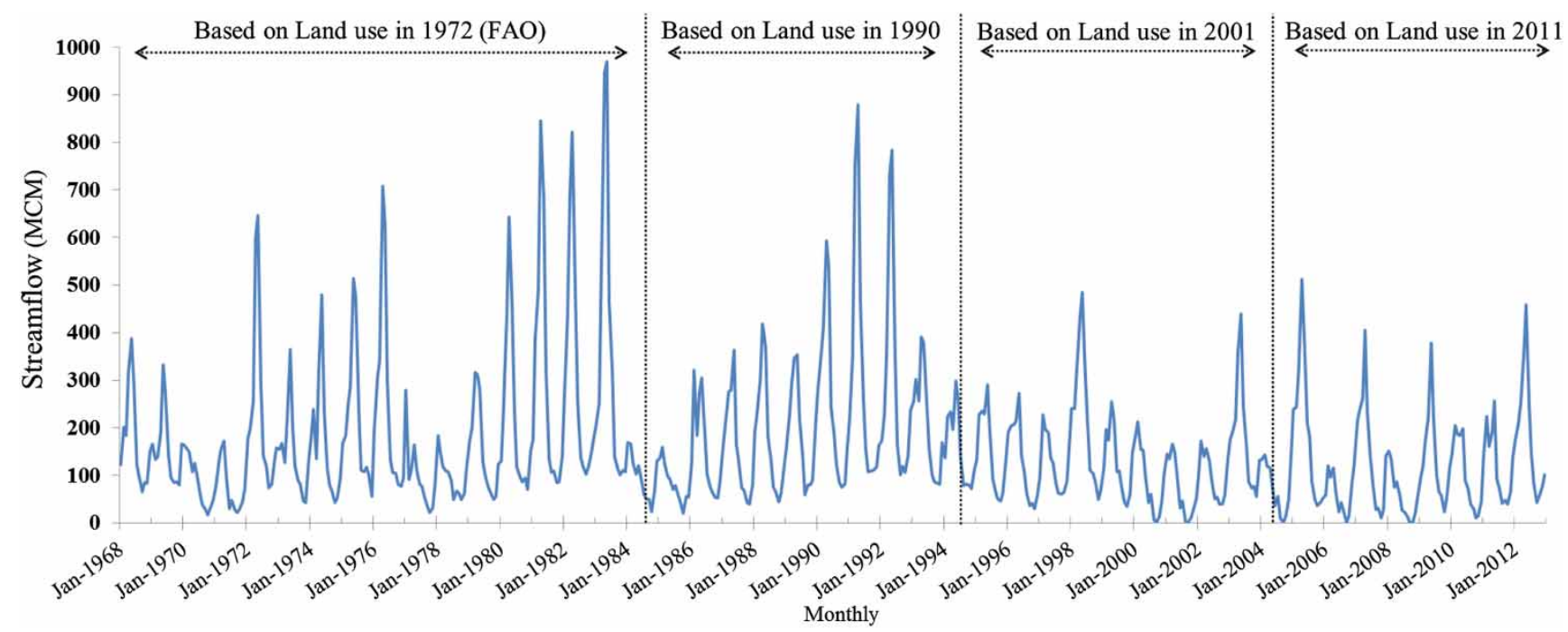

Figure 15 | Streamflow simulated by the SWAT model at Char-Burjak station (1968-2012). 


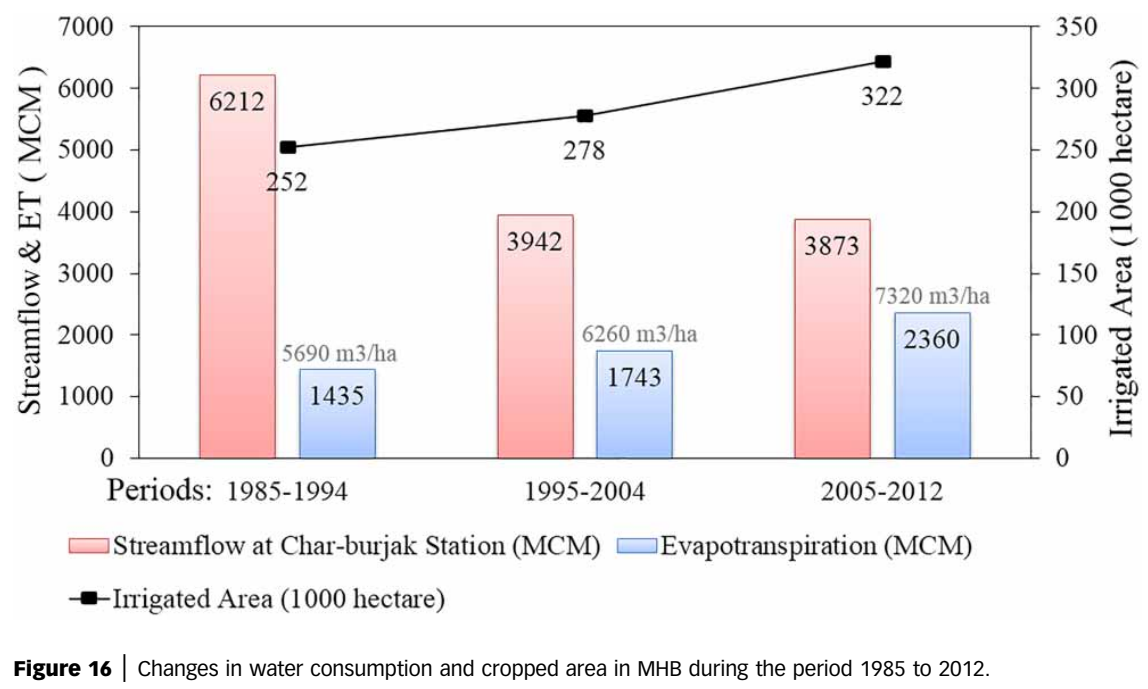

4,787 MCM/year, while employing the land use of 1990 from the beginning of the simulations, the average annual discharge was 5,133 MCM/year. Therefore, the agricultural developments in MHB decreased the discharge with about $346 \mathrm{MCM} / \mathrm{year}$. The increase of 64,000 ha in an irrigated area in MHB after 1990 and the $346 \mathrm{MCM}$ decrease in discharge resulted in $5,400 \mathrm{~m}^{3} / \mathrm{ha}$ of evapotranspiration, which is very close to the reports of FAO for the study area (FAO 20I5).

4. In order to study changes in discharge time series due to climate variability, possible trends in the climate data were evaluated using the Mann-Kendall test. The results showed that there is no significant trend in climate variables except for the minimum temperature. Furthermore, the Pettitt test was also applied and detected meaningful changes in 1976. While the recorded average annual minimum temperature was $1.5^{\circ} \mathrm{C}$ (1941 to 2012), its detrended value reduced to $0.9^{\circ} \mathrm{C}$.

5. The results showed that the relative impact of land use changes during the first period (1985-1994) was only 45 MCM. The climate variability has the same, small impact. Notably, the impact of land use change increased significantly for more recent periods and caused a reduction of $810 \mathrm{MCM}$ in annual streamflow for the MHB (i.e. outflow from Char-Burjak station).

6. The amount of actual evapotranspiration per hectare has increased from 5,690 to $7,320 \mathrm{~m}^{3}$ in the period of 1985 to 2012. The reason for this drastic change can be attributed to the increase of the double cropping area in the basin.
7. The methodology can be applied for long-term hydrological assessments of other transboundary river basins in data-scarce regions.

\section{CONFLICTS OF INTEREST STATEMENT}

None declared.

\section{REFERENCES}

Abbaspour, K. C. 2007 User Manual for SWAT-CUP. SWAT Calibration and Uncertainty Analysis Programs. Swiss Federal Institute of Aquatic Science and Technology, Eawag, Dübendorf, Switzerland, p. 95.

Abbaspour, K. C., Faramarzi, M. \& Rouholahnejad, E. 2010 Hydrological Modeling of Alberta Using SWAT Model. A preliminary Report.

Arnold, J. G., Srinivasan, R., Muttiah, R. S. \& Williams, J. R. 1998 Large area hydrologic modeling and assessment part I: model development. Journal of the American Water Resources Association 34 (1), 73-89. https://doi.org/10. 1111/j.1752-1688.1998.tb05961.x.

Bitew, M. M. \& Gebremichael, M. 20II Assessment of satellite rainfall products for streamflow simulation in medium watersheds of the Ethiopian highlands. Hydrology and Earth System Sciences 15, 1147-1155. https://doi.org/10.5194/ hess-15-1147-2011.

Congalton, R. G. I99I A review of assessing the accuracy of classifications of remotely sensed data. Remote Sensing of Environment 37, 35-46. https://doi.org/10.1016/00344257(91)90048-B. 
Congalton, R. G. \& Green, K. I999 Assessing the Accuracy of Remotely Sensed Data: Principles and Practices. Lewis Publishers, Boca Raton, FL, p. 137.

Döll, P., Kaspar, F. \& Lehner, B. 2003 A global hydrological model for deriving water availability indicators: model tuning and validation. Journal of Hydrology 270, 105-134.

Dong, L., Zhang, G. \& Xu, Y. 2012 Effects of climate change and human activities on runoff in the Nenjiang River Basin, Northeast China. Hydrology and Earth System Sciences 9, 11521-11549. https://doi:10.5194/hessd-9-11521-2012.

FAO (Food and Agriculture Organization) 1995 The Digital Soil Map of the World and Derived Soil Properties. CD-ROM Version 3.5, Rome.

FAO (Food and Agriculture Organization) 2015 Analysis on Water Availability and Uses in Afghanistan River Basins, Water Accounting Through Remote Sensing (WA+) in Helmand River Basin. FAO project TCP/AFG/3402.

Favre, R. \& Kamal, G. M. 2004 Watershed Atlas of Afghanistan, First Edition - Working Document for Planners. Ministry of Irrigation, Water Resources and Environment, Afghanistan and FAO.

Geng, S., Penning de Vries, F. W. T. \& Supit, I. 1986 A simple method for generating daily rainfall data. Agricultural and Forest Meteorology 36, 363-376. https://doi.org/10.1016/ 0168-1923(86)90014-6.

Griensven, A. V., Ndomba, P. \& Yalew, S. 2012 Critical review of SWAT applications in the upper Nile basin countries. Hydrology and Earth System Sciences 16, 3371-3381. https:// doi.org/10.5194/hess-16-3371-2012.

Hajihoseini, H. R., Hajihoseini, M. R., Morid, S., Delavar, M. \& Booij, M. J. 2016 Hydrological assessment of the 1973 treaty on the transboundary Helmand river, using the SWAT model and a global climate database. Water Resource Management 30, 4681-4694. https://doi.10.1007/s11269-016-1447-y.

Hamlet, A. F. \& Lettenmaier, D. P. 2007 Effects of 20th century warming and climate variability on flood risk in the western U.S. Water Resources Research 43, W06427. https://doi:10. 1029/2006WR005099.

Harris, I., Jones, P. D., Osborn, T. J. \& Lister, D. H. 2013 Updated high-resolution grids of monthly climatic observations - the CRU TS3.10 dataset. International Journal of Climatology 34 (3), 623-642. https://doi.org/10.1002/joc.3711.

Helmand River Delta Commission 195I Report of the Helmand River Delta Commission, Afghanistan and Iran. Washington, D. C dated February 28.

Hongming, H., Zhou, J. \& Zhang, W. 2008 Modelling the impacts of environmental changes on hydrological regimes in the Hei River Watershed, China. Global and Planetary Change 61, 175-193. https://doi.org/10.1016/j.gloplacha.2007.08.012

Huang, C., Davis, L. S. \& Townshend, J. R. G. 2002 Assessments of Support Vector Machine for land cover classification. International Journal of Remote Sensing 23 (4), 725-749. https://doi:10.1080/01431160110040323.

Huo, Z., Feng, S., Kang, S., Li, W. \& Chen, S. 2008 Effect of climate changes and water-related human activities on annual stream flows of the Shiyang river basin in arid northwest China. Hydrological Processes 22, 3155-3167. https:// doi.org/10.1002/hyp.6900.

Karlsson, M. \& Yakowitz, S. 1987 Nearest-neighbor methods for nonparametric rainfall runoff forecasting. Water Resources Research 23, 1300-1308. https://doi.10.1029/ WR023i007p01300.

Kendall, M. G. 1975 Rank Correlation Methods. Griffin, London, UK. https://doi.10.4236/ojdm.2015.54006.

Khoi, D. N. \& Hang, P. T. T. 2015 Uncertainty assessment of climate change impacts on hydrology: a case study for the central highlands of Vietnam. Managing Water Resources Under Climate Uncertainty. Springer Water. https://doi.10. 1007/978-3-319-10467-6_2.

Khoi, D. N. \& Suetsugi, T. 20I4 Impact of climate and land-use changes on hydrological processes and sediment yield - a case study of the Be River catchment, Vietnam. Hydrological Sciences Journal 59 (5). http://dx.doi.org/10.1080/02626667. 2013.819433

Knorn, J., Rabe, A., Radeloff, C. \& Kuemmerle, T. 2009 Land cover mapping of large areas using chain classification of neighboring Lanmadsat satellite images. Remote Sensing of Environment 113, 957-964. https://doi.10.1016/j.rse.2009.01.010.

Li, Y., Chang, J., Wang, Y., Jin, W. \& Guo, A. 2016 Spatiotemporal impacts of climate, land cover change and direct human activities on runoff variations in the Wei River Basin, China. Water 8, 220. http://doi:10.3390/w8060220.

Liu, Z. F., Tian, L. D., Yao, T. D., Gong, T. L., Yin, C. L. \& Yu, W. S. 2007 Temporal and spatial variations of $\mathrm{d} 18 \mathrm{o}$ in precipitation of the Yarlung Zangbo River Basin. Journal of Geographical Sciences 17, 317-326.

Louis Berger Group Inc. 2004 Kajakai Hydroelectric Project Condition Assessment, Dam Safety Assessment Report.

Mahesh, P. \& Mather, P. M. 2003 An assessment of the effectiveness of decision tree methods for land cover classification. Remote Sensing of Environment 86, 554-565. http://dx.doi.org/10.1016/S0034-4257(03) 00132-9.

Manandhar, R., Odeh, A. \& Ancev, T. 2009 Improving the accuracy of land use and land cover classification of landsat data using post-classification enhancement. Journal of Remote Sensing 1, 330-344. http://doi:10.3390/rs1030330.

Mango, L. M., Melesse, A. M. \& McClain, M. E. 2on Land use and climate change impacts on the hydrology of the upper Mara River Basin, Kenya: results of a modeling study to support better resource management. Hydrology and Earth System Sciences 15, 2245-2258. http://doi:10.5194/hess-15-2245-2011.

Mann, H. B. 1945 Nonparametric tests against trend. Econometrica 13, 245-259. http://dx.doi.org/10.2307/1907187.

Marhaento, H., Booij, M. J. \& Hoekstra, A. Y. 20I7a Attribution of changes in stream flow to land use change and climate change in a mesoscale tropical catchment in Java, Indonesia. Hydrology Research 48, 1143-1155. https://doi.org/10.2166/ nh.2016.110.

Marhaento, H., Booij, M. J., Rientjes, T. H. M. \& Hoekstra, A. Y. $2017 \mathrm{~b}$ Attribution of changes in the water balance of a tropical 
catchment to land use change using the SWAT model. Hydrological Processes 31, 2029-2040. http://doi: 10.1002/ hyp.11167.

Mojtahed-Zadeh, P. 2006 Hydropolitics of Hirmand and Hamun. In: Boundary Politics and International Boundaries of Iran: A Study of the Origin, Evolution, and Implications of the Boundaries of Modern Iran with its 15 Neighbors in the Middle East, the Persian Gulf, the Caucasus, the Caspian Sea, Central Asia, and West Asia by A Number of Renowned Experts in the Field (P. Mojtahed-Zadeh, ed.). Universal Publishers, Boca Raton, FL.

NCDC 2ого Climatology for Southwest Asia. National Climatic Data Center.

Neitsch, S. L., Arnold, J. G., Kiniry, J. R. \& Williams, J. R. 2005 Soil and Water Assessment Tool Theoretical Documentation.

Otukei, T. R. \& Blaschke, T. 20Io Land cover change assessment using decision trees, support vector machines and maximum likelihood classification algorithms. International Journal of Applied Earth Observation and Geoinformation 12S, S27-S31. http://dx.doi.org/10.1016/j.jag.2009.11.002.

Partal, T. \& Kahya, E. 2006 Trend analysis in Turkish precipitation data. Hydrological Processes 20. http://doi.10.1002/hyp. 5993.

Schuol, J. \& Abbaspour, K. C. 2006 Using monthly weather statistics to generate daily data in a SWAT model application to West Africa. Ecological Modelling 201, 301-311. http:// doi.10.1016/j.ecolmodel.2006.09.028.

Schuol, J., Abbaspour, K. C., Yang, H., Srinivasan, R., Alexander, J. \& Zehnder, B. 2008 Modeling blue and green water availability in Africa. Journal of Water Resources Research 44, W07406. http://doi.10.1029/2007WR006609.

Shi, P., Xinxin, M. \& Yuanbing, H. 2013 Effects of land-use and climate change on hydrological processes in the upstream of Huai River, China. Journal of Water Resources Management 27, 1263-1278. http://doi 10.1007/s11269-012-0237-4.

Stefano, L., Silva, L., Edwards, P. \& Wolf, A. 2009 Updating the International Water Events Database. UNESCO, United Nations Educational, Scientific and Cultural Organization.

Tomer, M. D. \& Schilling, K. E. 2009 A simple approach to distinguish land-use and climate-change effects on watershed hydrology. Journal of Hydrology 376, 24-33. http://doi 10. 1016/j.jhydrol.2009.07.029.

UNEP 2006 History of Environmental Change in the Sistan Basin, Based on Satellite Image Analysis: 1976-2005. Post-Conflict Branch Geneva, (ITC) Netherlands.

United Nation Office on Drugs and Crime (UNODC) 2016 Afghanistan Opium Survey. Cultivation and Production, Kabul.

Vapnik, V. 1999 The Nature of Statistical Learning Theory, 2nd edn. Springer.

Vining, K. C. \& Vecchia, A. V. 2007 Water Balance Simulations of Runoff and Reservoir Storage for the Upper Helmand Watershed and Kajakai Reservoir, Central Afghanistan. U.S. Geological Survey Scientific (USGS) Investigations Report
2007-5148, Reston, VA, p. 16. http://pubs.usgs.gov/sir/2007/ 5148.

Vuyovich, C. M. \& Jacobs, J. M. 20II Snowpack and runoff generation using AMSR-E passive microwave observations in the Upper Helmand Watershed, Afghanistan. Remote Sensing of Environment 115, 3313-3332. http://doi: 10.1016/ j.rse.2011.07.014.

Wang, X. 2014 Advances in separating effects of climate variability and human activity on stream discharge: an overview.

Journal of Advances in Water Resources 71, 209-218. http:// dx.doi.org/10.1016/j.advwatres.2014.06.007.

Williams-Sether, T. 2008 Streamflow Characteristics of Streams in the Helmand Basin, Afghanistan. U.S. Geological Survey (USGS) Data Series 333, p. 341. http://pubs.usgs. gov/ds/333/.

Xu, H., Taylor, R. G. \& Xu, Y. 2orr Quantifying uncertainty in the impacts of climate change on river discharge in subcatchments of the Yangtze and Yellow River Basins, China. Hydrology and Earth System Sciences 15, 333-344. http:// doi:10.5194/hess-15-333-2011.

Yang, T., Xu, C. Y., Chen, X., Singh, V. P., Shao, Q. X., Hao, Z. C. \& Tao, X. 20Io Assessing the impact of human activities on hydrological and sediment changes (1953-2000) in nine major catchments of the Loess Plateau, China. River Research and Applications 26, 322-340.

Ye, X., Zhang, Q., Liu, J., Li, X. \& Xu, C. 2013 Distinguishing the relative impacts of climate change and human activities on variation of stremflow in the Poyang Lake catchment, China. Journal of Hydrology 494, 83-95. http://dx.doi.org/10.1016/ j.jhydrol.2013.04.036.

Yin, J., He1, F., Xiong, Y. \& Qiu, G. 2017 Effects of land use/land cover and climate changes on surface runoff in a semi-humid and semi-arid transition zone in northwest China. Hydrology and Earth System Sciences 21, 183-196. http://doi:10.5194/ hess-21-183-2017.

Yong, C., Marek, G. W., Marek, T. H., Brauer, D. K. \& Srinivasan, R. 2017 Assessing the efficacy of the SWAT auto-irrigation function to simulate irrigation, evapotranspiration, and crop response to management strategies of the Texas high plains. Journal of Water 9, 509. https://doi.org/10.3390/ w9070509.

Zarezadeh, M., Morid, S., Karimi, N., Madani, K. \& Fatemi, F. 2018 The trend and future prospect of agricultural land development in Afghanistan's Helmand River Basin based on satellite images and GEOMOD method. Iranian Journal of Irrigation and Drainage 1-12, 209-221.

Zhang, Y., Guan, D., Jin, C., Wang, A., Wua, J. \& Yuan, F. 2on Analysis of impacts of climate variability and human activity on streamflow for a river basin in northeast China. Journal of Hydrology $\mathbf{4 1 0}$, 239-247. http://doi:10.1016/j.jhydrol.2011.09.023.

Zhi, Z., Liu, W., Zhang, X. \& Zheng, F. 2009 Impacts of land use change and climate variability on hydrology in an agricultural catchment on the Loess Plateau of China. Journal of Hydrology 377, 35-42. http://doi:10.1016/j.jhydrol.2009.08.007.

First received 25 May 2019; accepted in revised form 28 September 2019. Available online 18 October 2019 